\title{
The influences of contract structure, contracting process, and service complexity on supplier performance
}

\author{
Wenting Zou \\ Department of Industrial Engineering and Management, \\ Aalto University School of Science, Espoo, Finland \\ Saara A. Brax \\ School of Business and Management, LUT University, Lappeenranta, Finland, and \\ Mervi Vuori and Risto Rajala \\ Department of Industrial Engineering and Management, \\ Aalto University School of Science, Espoo, Finland
}

\begin{abstract}
Purpose - To build a more comprehensive understanding of factors affecting the success of service contracting, the purpose of this paper is to investigate the influences of service complexity, contract structure and contracting process on the buyer-perceived supplier performance in business-to-business (B2B) services. Design/methodology/approach - A research model is developed based on transaction cost economics and the research on service contracting. The model is tested by the survey data collected. Professional focus groups on LinkedIn are used to generate the list of potential respondents. The sample consists of 177 purchasing professionals from 25 countries.

Findings - The results indicate that three major contract dimensions and follow-up management practices positively influence buyer-perceived supplier performance. Furthermore, service complexity amplifies the effects of incentives designed in the contract and the buyer's follow-up contract management on perceived supplier performance.

Research limitations/implications - The sample consists of respondents from 25 countries and provides good geographic coverage. However, the results should be generalized with caution because not all countries were represented equally.

Practical implications - The study suggests a framework and guidelines for purchasing managers to improve the design and management of service contracts to secure good performance from their supplier.

Originality/value - This paper contributes to understanding the performance-enhancing aspects of designing and monitoring service contracts in $\mathrm{B} 2 \mathrm{~B}$ contexts. It also adds to the knowledge of the role of service complexity in successful B2B service purchasing.
\end{abstract}

Keywords Service contract, B2B services, Perceived supplier performance, Service complexity,

Service purchasing, Transaction cost economics (TCE)

Paper type Research paper

\section{Introduction}

Reflecting the global transition of industrial firms' business models toward increasing reliance on services, service purchasing has become a more salient activity in inter-organizational exchange (Axelsson and Wynstra, 2002; Pemer et al., 2014; Van Der Valk and Wynstra, 2012).

(C) Wenting Zou, Saara A. Brax, Mervi Vuori and Risto Rajala. Published by Emerald Publishing Limited. This article is published under the Creative Commons Attribution (CC BY 4.0) licence. Anyone may reproduce, distribute, translate and create derivative works of this article (for both commercial and non-commercial purposes), subject to full attribution to the original publication and authors. The full terms of this licence may be seen at http://creativecommons.org/licences/by/4.0/legalcode

The authors express gratitude to the anonymous reviewers and the editor for helpful comments that improved the paper. Funding parties have not participated in the research and had no influence on the results.

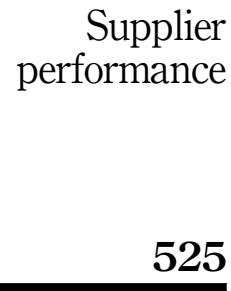

Received 22 December 2016 Revised 20 July 2017

23 November 2017

16 February 2018

15 June 2018

5 October 2018

Accepted 14 November 2018 
IJOPM

39,4

This transition gives rise to the rationale that companies can improve their performance by focusing on their core activities while letting specialist service providers take care of other activities (Ellram et al., 2008; Stouthuysen et al., 2012). Hence, there is an increasing need for companies to improve their service purchasing.

Despite the potential benefits of well-managed service procurement, the inter-organizational exchanges related to business-to-business (B2B) services inevitably involve complexities that make it difficult to align service procurement with the exchange parties' objectives (Poppo and Zenger, 2002; Stouthuysen et al., 2012). Because services are essentially process-based offerings (Brax et al., 2017), their special characteristics can complicate their purchasing (Benedettini and Neely, 2012; Roehrich and Lewis, 2014). From the buyer's perspective, the characteristics that complicate the specification of service contracts with suppliers are the intangibility of the offering, context-dependence of the value created, heterogeneity of resources and outcomes related to a service, and inseparability of the production from the consumption of a service (Axelsson and Wynstra, 2002; Datta and Roy, 2011; Van Der Valk and Rozemeijer, 2009). According to the transaction cost economics (TCE) perspective, purchasers should pursue supplier governance mechanisms, because complexities of the contracting process can induce opportunism in buyer-supplier relationships and, thus, increase the risk of poor supplier performance (Huo et al., 2016; Wacker et al., 2016; Williamson, 1985).

A fundamental issue in service purchasing is the asymmetry of information between buyers and suppliers. Even though suppliers depend on buyers to define their needs, requirements and the context of use, buyers may lack the knowledge and skills to articulate these elements to suppliers (Aarikka-Stenroos and Jaakkola, 2012; Stauss et al., 2010). Literature in TCE suggests that information asymmetry between service providers and customers is another factor that gives rise to opportunism (Susarla et al., 2009; Williamson, 1985), which then increases the difficulty of predicting the behavior of suppliers. In general, service deliveries are difficult to describe in contracts due to the uncertainties in specifying the desired outcome or the steps to achieve it (Anderson and Dekker, 2005). For example, when a firm purchases complex services, details of the requirement specification often remain unclear, so the performance details and relevant costs cannot be conclusively determined (Ellram et al., 2008). Additionally, services often have the interdependent and interactive character of co-production between buyers and suppliers (Brax et al., 2017). This can also give exchange partners the room to engage in opportunistic behavior that may result in a poor delivery of the service (Stouthuysen et al., 2012). Because of these challenges, designing contract structure and managing the contracting process have become key elements for buying organizations to ensure supplier performance in B2B contexts (Datta and Roy, 2013).

The process-based nature, complexity and continued duration of many B2B services (Brax and Jonsson, 2009) imply that designing purchasing contracts and managing contracting process can be much more complicated for business services than for goods. Therefore, conventional supply contracts and prescribed specifications that guide the exchange of goods are not suitable for B2B services procurement. Especially when companies move toward advanced availability, capability, and performance-based services, they required new buying practices (Baines et al., 2011).

The servitization literature focuses on the importance of contractual and relational governance for service contracts (Enquist et al., 2011; Ferguson et al., 2005; Roehrich and Lewis, 2014). The interplay of contractual and relational governance has received considerable attention in service procurement arrangements (Cao and Lumineau, 2015; Zheng et al., 2008). To ensure effective service delivery, empirical studies show that companies must have appropriate contractual and relational capabilities to write, interpret and manage complex service contracts (Ferguson et al., 2005; Kreye et al., 2015; Zheng et al., 2008). Companies that purchase advanced services need these capabilities to design contracts to ensure the buyer's perception of good supplier performance (Van Der Valk and 
Wynstra, 2014). However, very little work has provided guidance on which dimensions or agreements should be incorporated into the service contracts that improve perceived supplier performance.

The importance and complexity of contracts increase with the complexity of the service (Van Der Valk and Wynstra, 2014), as contracts differentiate the main business model types that are implemented in complex product-service-systems (PSS) offerings (Azarenko et al., 2009; Ng et al., 2013; Reim et al., 2015; Tukker, 2004). Buyer companies, especially those that are shifting from buying goods to buying services, struggle with the lack of knowledge on designing contract structure and managing contracting process for B2B services (Datta and Roy, 2011; Oliva and Kallenberg, 2003). For example, buyers have to anticipate the usual risks of poor service performance (Stouthuysen et al., 2012). However, while research attention to this area has recently burgeoned, the earlier research on contracting in complex $\mathrm{B} 2 \mathrm{~B}$ service contexts tends to be grounded in case studies representing the supplier side; there is also a noticeable emphasis on the defense industry in case selection (Grubic and Jennions, 2017; Kleemann and Essig, 2013; Kreye et al., 2014; Ponsignon et al., 2011). Therefore, further empirical research is needed to examine the design of contract structure and management of the contracting process between buyers and suppliers and how these influence the supplier performance perceived by the buyer. There is an urgent need to investigate the influence of service complexity and relationship management on supplier performance to improve today's research-based knowledge of the effects of contract structure and contracting process on service supplier performance. In addition, the lack of variety in research methodology and industry representation points to the need for balance.

The present study draws on the TCE theory to explain how the complexities of service purchasing may influence supplier performance. However, because TCE does not fully explain the complexity of service contracting, the current study extends its research model to investigate supplier governance mechanisms that aim to prevent opportunism and ensure the fulfillment of contractual obligations by the supplier (Wacker et al., 2016). Hence, this research adds to TCE by examining elements of the contract structure and contracting process characteristic of service purchasing.

Using survey data collected from 177 purchasing professionals from 25 countries, this study examines how three dimensions of contract structure and post-contract management influence supplier performance as perceived by the buyer in B2B contexts. These three contract dimensions are the definition of responsibilities, performance criteria and incentives. Assuming that service complexity increases the importance of contract design and contracting process management in a successful service outcome, this study examines the effect of the complexity of the purchased services on this relationship.

The paper is organized as follows. The next section outlines the conceptual background of the study and establishes the hypotheses. The subsequent section describes the research method, the data and the analyses conducted. Thereafter, the paper presents the results of the empirical study. The last two sections are devoted to discussing the observations and implications of this work in terms of the ways in which service complexity influences the relationships among contract structure, the contracting process and customer-perceived supplier performance.

\section{Theory and hypotheses}

\subsection{Perceived supplier performance}

Prior empirical studies have shown that a buyer's perception of supplier performance is the main consequence of the supplier's actual performance in influencing the buyer's decision to continue the relationship (Poppo and Zenger, 2002; Stouthuysen et al., 2012). Moorman et al. (1992) demonstrated that buyers who perceive their supplier performance more positively are more confident in continuing to transact business with this supplier; also, perceived supplier performance increases trust in and loyalty to the supplier. Thus, in line with 
IJOPM

39,4

previous research on purchasing services (Bastl et al., 2012; Cannon et al., 2000; Johnston et al., 2004; Modi and Mabert, 2007; Stouthuysen et al., 2012; Van Der Valk and Wynstra, 2014), this study relies on the customer's perception of supplier performance rather than the supplier's objective economic performance. In the TCE theory, the costs of a transaction are often divided into three main categories: information costs, negotiation costs and monitoring costs (cf. Carter and Hodgson, 2006), all of which influence the performance of the contracting process. Hence, in addition to covering the essential transaction dimensions, a comprehensive explanation of supplier performance should include the governance mechanisms that address these costs of contracting.

In $\mathrm{B} 2 \mathrm{~B}$ service exchanges, perceived supplier performance means that buyers evaluate several explicit and implicit aspects of the delivered services to assess the effectiveness of the interfirm relationship (Johnston et al., 2004; Stouthuysen et al., 2012). The focus is on evaluating the performance of a service supplier through all service episodes instead of only one (Smeltzer and Ogden, 2002). According to Cousins et al. (2008), buyers should continuously monitor supplier performance across a variety of dimensions. Therefore, we examine the buyer's satisfaction with the supplier performance, where the underlying logic is that overall satisfaction is a focal consequence of a working partnership (Poppo and Zenger, 2002). This is consistent with previous measurements of perceived supplier performance in the literature (Ferguson et al., 2005; Li et al., 2010; Stouthuysen et al., 2012).

\subsection{Contract structure - major contract dimensions}

TCE provides insights into the costs of contractual exchange, which determines the type of contractual governance arrangements to minimize the costs of transacting (Donato, 2010; Williamson, 1985). Contracts are explicit (usually written, often detailed) and formal arrangements that stipulate the legally binding obligations and roles of both parties in a relationship (Lyons and Mehta, 1997). In this sense, contracts are essential transaction mechanisms in service operations. Also, contracts provide a formal governance structure for the interactions between buyers and suppliers, and they may prevent opportunistic behavior in the transaction (Wacker et al., 2016). According to TCE, a detailed contract limits opportunistic behavior by stipulating mutual expectations (Chang et al., 2017; Huo et al., 2016). In service procurement, the contextual characteristics of services increase complexity and uncertainty, and thus neither buyers nor service providers have complete information to specify all the necessary safeguards and contingencies due (Roehrich and Lewis, 2014; Zheng et al., 2008). This contractual incompleteness may allow opportunistic suppliers to exploit contracts to their own advantage at the expense of service performance (Brown et al., 2006). This leads to demanding service contract design processes in order to ensure good service performance with the minimal transaction costs (Brown et al., 2006; Poppo and Zenger, 2002; Susarla et al., 2009). One of the tenets of TCE is that transaction characteristics determine transaction costs and the optimal buyer-supplier governance structure (Wynstra et al., 2018). Therefore, service-buying organizations should craft governance arrangements to match the exchange conditions that accompany the specific type of service acquired (Enquist et al., 2011; Mills et al., 2013; Poppo and Zenger, 2002).

According to the TCE perspective, three transaction characteristics determine transaction costs: asset specificity, measurement difficulty and uncertainty (Poppo and Zenger, 2002; Williamson, 1985). Asset specificity relates to the relationship-specific investment in resources. This investment can generate hazards of hold-up behavior because one party in the relationship may seek to appropriate gains, such as reducing service quality or raising prices, from the other party's specific investments (Donato, 2010). Difficulty in measuring the service performance also generates hazards. When performance is difficult to measure, suppliers may limit their efforts to fulfill the agreement (Poppo and Zenger, 2002). For example, the supplier may cut corners since the buyer cannot measure it. 
The empirical study conducted by Susarla et al. (2009) identified that contracts that are designed in accordance with transaction cost minimization outperform contracts that are not. To reduce the transaction costs of asset specificity and measurement difficulty, we identify three dimensions of the contract structure: definition of responsibilities, performance criteria and incentives. These dimensions are consistent with the two frameworks presented by Jensen and Meckling (1995) and Whang (1992) in the management control literature. These frameworks are used to interpret the structure of contract design (Anderson and Dekker, 2005). The following section elaborates each dimension.

Definition of responsibilities describes the accountabilities of service providers and customers. B2B service contracts tend to focus on achieving a required outcome rather than fulfilling a set of prescribed specifications that traditionally guides the exchange of goods (Datta and Roy, 2013; Gruneberg et al., 2007; Zheng et al., 2008). According to TCE, detailing responsibilities is one way to guard against misunderstandings and mitigate opportunism (Malatesta and Smith, 2014). The responsibilities of buyers and suppliers reduce transactional ambiguity by providing a clear specification of what will and will not be allowed within a relationship (Lui and Ngo, 2004). Service exchanges between two parties generally involve high asset specificity (Brown et al., 2006; Lonsdale, 2001), which increases the importance of responsibilities for protection against opportunism (Wacker et al., 2016). The service contract should stipulate the rights and obligations of buyers and suppliers through formal rules, terms and procedures. It explicitly demonstrates how various future situations will be addressed (i.e., responsibilities for service performance, delivery procedure, responsibilities for the supplier's operative processes and its personnel, penalties for noncompliance, etc.) (Heikkilä et al., 2013; Liu et al., 2009). In addition, a framework of two parties' responsibilities for resolving unforeseen disputes should be specified (Poppo and Zenger, 2002). Therefore, crafting a service contract that clarifies the responsibilities of both parties can reduce role conflicts and ambiguity, guide task fulfillment and better monitor the ongoing exchange between buyers and suppliers (Liu et al., 2009). This could mitigate the opportunism of the service supplier and motivate better performance outcomes (Brown et al., 2006; Chang et al., 2017). These observations are the basis of the first hypothesis:

H1. In B2B service contract design, a definition of responsibilities positively influences perceived supplier performance.

Performance criteria are defined in contracts to identify and describe the target performance level and the output; this is essential for the successful delivery of long-term service contracts (Enquist et al., 2011; Robinson and Scott, 2009). The performance measurement designed in the contracts makes it easier for both parties to understand the process, competencies and assets required to deliver the required level of performance. TCE states that performance ambiguity increases opportunism for both supplier and buyer (Wacker et al., 2016; Williamson, 1985). On the one hand, the supplier could take advantage of poor service specifications and not fulfill important requirements. On the other hand, the buyer could use poor service specifications to claim that some specifications were implicit in the agreement (Wacker et al., 2016). Therefore, buying companies should expand their resources to clarify their requirements for supplier performance (Poppo and Zenger, 2002). Setting performance criteria indicators requires careful consideration because pre-set performance indicators such as quality, speed and flexibility require an understanding of the service provider's operational capabilities (Datta and Roy, 2011; Van Der Valk et al., 2016). The performance indicators defined in the contractual agreements can raise the understanding of contractual fulfillment and performance specifications, and be measured to indicate the cause of future problems, thereby they enhance the performance of service providers (Datta and Roy, 2011; Roehrich and Lewis, 2010). Correspondingly, imprecise specifications 
IJOPM

39,4

530

increase buyers' inability to accurately assess their supplier's performance and, therefore, decrease their satisfaction with suppliers. Therefore, the second hypothesis is:

H2. In B2B service contract design, performance criteria positively influence perceived supplier performance.

Incentives are used in the contracts to transfer risks and ensure compliance with performance measures, aligning the goals of the two parties concerned and motivating their cooperation (Datta and Roy, 2011; Robinson and Scott, 2009). Incentive design is one mechanism used in contracting for linking the coordination of required resources to the business model (Datta and Roy, 2013). The TCE perspective suggests that the incentives should describe the cooperation and continuity after transaction-specific investments and penalties in case of a supplier's breach of service delivery. Besides, incentives should include risk sharing between the buyer and the supplier to enhance inter-organizational collaboration (Wacker et al., 2016). The complexity of services increases difficulties in defining the service specifications, which may add to the uncertainties of service delivery and risks of poor service performance. Risk sharing as a relationship-bound economic incentive can guide buyer-supplier exchanges and promote accountability (Wathne and Heide, 2000). Datta and Roy (2013) found that sharing risks between buyers and suppliers leads to better profitability for both parties, in contrast to one party carrying the entire risk. In addition, earlier research has linked well-defined incentives in the contracts to improved service delivery and supply chain performance (Narayanan and Raman, 2004; Robinson and Scott, 2009). Thus, the following hypothesis is proposed:

H3. In B2B service contract design, incentives positively influence perceived supplier performance.

Although the literature, dominated by case research, emphasizes these three dimensions in the design of contractual agreements for effective service delivery, the actual impact of these dimensions on supplier performance remains untested.

\subsection{Contracting process - follow-up management}

Uncertainty is the third notable source of transaction costs according to TCE. It challenges an exchange by addressing the unforeseeable contingencies through two parties' adaptation (Susarla et al., 2009). Since many services cannot be fully specified in the contracts before services are delivered (Kreye et al., 2015; Roehrich and Lewis, 2010), inter-organizational relationships are characterized by a degree of uncertainty that makes these contracts unenforceable in their entirety (Kreye et al., 2015). The uncertainty arising from incomplete specifications demands for the involved parties to coordinate and adapt to unforeseeable problems during the service contracting period (Broekhuis and Scholten, 2018; Poppo and Zenger, 2002). This necessitates designing a contracting process that monitors and evaluates suppliers once the transaction is underway. It emphasizes management practices to monitor and assess a supplier's performance based on pre-specified arrangements made during the contracting period (Huo et al., 2016; Selviaridis and Spring, 2010). The process, including management practices (e.g., frequent review meetings), allows buyers and suppliers to exchange information, renegotiate when circumstances change, modify the service specifications defined in the contracts, and even revise the contracts because the interaction through review meetings helps the two parties adopt a joint approach to problem solving that facilitates mutual adaptation (Roehrich and Lewis, 2014; Zheng et al., 2008). This allows the provider to implement continuous improvement practices throughout the contracting process (cf. Mills et al., 2013). Therefore, establishing management practices in the contracting process can compensate for ambiguities in the contracts while encouraging continuity and cooperation between the two parties (Poppo and Zenger, 2002; Zheng et al., 2008). 
Based on TCE and these arguments, a contracting process including management practices can reduce or prevent possible future opportunism arising from service uncertainty, and thus ensure effective service delivery. The management practices, as a form of process control, focus on how the outcomes are reached (Huo et al., 2016). Case studies by Roehrich and Lewis (2014) show that post-contract management practices are crucial to establishing feedback channels and increasing the team familiarity that can lead to improved service performance outcomes. Although the literature has noted these post-contract management practices, the actual impact of post-contract management on supplier performance remains untested. Therefore, it is reasonable to assume that a buyer's follow-up management of the contracting process can drive perceived supplier performance as follows:

H4. The buyer's follow-up management of a contracting process positively influences perceived supplier performance.

\subsection{Service complexity}

Complexity is a fundamental characteristic of a service. Complexity in service may arise from numerous factors, including the heterogeneity of contextual factors, interrelated elements, use of sophisticated technologies, need for interactions between the customer and the provider. For example, Apte and Vepsäläinen (1993) assess service complexity by the number of options and contingencies to be considered in establishing a service contract. Moreover, Reim et al. (2015) defined PSS as highly demanding offerings in terms of the degree of customization, discretion, process focus, importance to the business, as well as the degree of uniqueness and uncertainty of the purchased service to the business. This conceptualization complements the view of service complexity. In PSS, complexity further arises from the broad scope of the service delivery and the technical complexity of the tangible systems, which increase requirements for expert capabilities (Ayala et al., 2019).

From the transaction cost perspective (Williamson, 1985), inefficiency and excessive costs occur in service transactions when making use of standardized transactions to satisfy a complex need, and in offering simple services through customized procedures (Apte and Vepsäläinen, 1993). Mass service exchanges typify a low level of service complexity but involve numerous transactions, limited contact time and little customization (Silvestro et al., 1992). These service exchanges focus on what a customer buys instead of on how the service is delivered (Oliva and Kallenberg, 2003;

Silvestro, 1999). In contrast, professional service exchanges often illustrate a high level of service complexity require significant customization and expertise, and involve few transactions (Stouthuysen et al., 2012). These service exchanges are process-oriented and put great emphasis on how the service is delivered to the customer (Silvestro et al., 1992). Based on the previous studies, this study uses a definition of complexity that is associated with the characteristics of the services.

The complexity of services decreases the level of transactional transparency and the possibility of direct reciprocity and responsibility (Kreye, 2019; Schmoltzi and Wallenburg, 2012). From TCE perspective, complexity increases the risks of opportunism and demands for more costly formal control mechanisms (Handley and Benton, 2013). Prior studies indicate that the complexity of the service increases the need for detail in the contract (Kreye et al., 2015; Poppo and Zenger, 2002). Efficient contracts should encompass promises, responsibilities and the process for dispute resolution. Without efficient, formal contractual governance, service complexity increases the effort to coordinate and monitor the activities (Schmoltzi and Wallenburg, 2012). Furthermore, the complexity of services increases information asymmetry and potential misunderstanding between buyers and suppliers, which then amplifies role ambiguity and uncertainty (Handley and Benton, 2013; Li et al., 2010; Schmoltzi and Wallenburg, 2012). 
IJOPM

39,4

532

The challenge of designing efficient contracts decreases the motivation of service suppliers to design highly specified contract structures. Yet, empirical evidence shows that the absence of such operational formalization deliveries negatively influences supplier performance (Gao et al., 2018), and contractual governance necessitates to constrain opportunism when service complexity is high (Malhotra and Lumineau, 2011). Prior studies have shown that service complexity increases the importance of contract structure on supplier performance (Datta and Roy, 2011, 2013). For instance, Datta and Roy (2011) demonstrated that the contracts specifying responsibilities and key performance indicators have become much more important in the effective delivery of highly complex services. In a study of outsourcing complex service solutions, they found that incentives including risk sharing between buyers and suppliers designed in the contract led to high and stable supplier performance and maximum profitability for all involved parties the long run (Datta and Roy, 2013). Clearly defining responsibilities, performance criteria, and incentives decrease role ambiguity and make supplier activities more predictable; thus, service complexity strengthens the effects of contract structure on supplier performance (Nakos and Brouthers, 2008).

As discussed above, the complexity of services increases the degree of uncertainty during service deliveries. According to information processing theory (IPT), uncertainty amplifies the needs for information processing and coordination (Handley and Benton, 2013; Larsen et al., 2013), which adds difficulty and the likelihood of problems during service delivery. The post-contract management practices can maintain regular and customary interaction, and structured information flows between buyers and suppliers, thereby mitigating problems with late adjustments (Faems et al., 2008). Furthermore, the buyer's follow-up management practices put forth rules for information exchange, which reduces the risk of information asymmetry. This also promotes continuous open communication between the two parties and fosters relationship bonding, which then enhances supplier performance (Schmoltzi and Wallenburg, 2012). Hence, the post-contract management practices are particularly effective when companies purchase complex services.

Based on these arguments, the contract structure and process are considered as critical contributors to service performance when firms purchase complex services. Therefore, we posit that service complexity increases the importance of contract structure and management to obtain the desired service performance. These arguments build the following hypotheses:

H5. Service complexity increases the impact of responsibilities defined in the contract on perceived supplier performance.

H6. Service complexity increases the impact of performance criteria specified in the contract on perceived supplier performance.

H7. Service complexity increases the role of incentives defined in the contract on perceived supplier performance.

H8. Service complexity increases the impact of the buyer's follow-up management in the contracting process on perceived supplier performance.

\subsection{Control variables}

Because perceived supplier performance in this study might be influenced by other factors, we controlled for three additional variables based on previous studies (Ferguson et al., 2005; Liu et al., 2009; Stouthuysen et al., 2012). These variables are perceived economic value, switching cost and buyer-supplier relationship bonds. Perceived economic value is a trade-off between benefits and sacrifices with a supplier's offering compared with 
competing alternatives (Arnott et al., 2007; Barry and Doney, 2011). The buyer's perceived supplier performance might be greater when that buyer believes that the supplier is better than the alternatives from an economic perspective (Mcdougall and Levesque, 2000). Switching cost is defined as the costs that a buyer incurs when changing from one service provider to another (Flint et al., 2011). Finally, relationship bonds are the personal ties or linkages fostered during interaction between a buyer and its supplier (Smith, 1998). These bonds might be an indicator of a buyer's psychological dependence on a supplier that influences the buyer's perception of supplier performance (Ferguson et al., 2005).

Figure 1 presents a model of the hypothesized relationships.

\section{Methodology}

Since the focus of the study is on the effects between the observed constructs, it uses a quantitative research approach. Among the four principal research strategies of the experiment, field research, survey and archival data (Singleton and Straits, 2009), the survey research design is the most suitable. Experiments are difficult to arrange, suitable archival data on service purchasing could not be found, and conducting enough case studies to allow quantitative analysis requires immense resources. Quantitative survey is an effective research strategy because the phenomenon of service contracting has already been studied in the case study literature (Forza, 2002; Singleton and Straits, 2009). The constructs that are not specific to the B2B service context (perceived supplier performance and three control variables) used in this study are well-defined in the literature. Other constructs (definition of responsibilities, performance criteria, incentives and follow-up management) and the relationships between contracting and performance are generally well-established in previous case studies. Building on the research on contracting, this study develops a research model and empirically tests it through the data collected.

\subsection{Sample and data collection}

The target sampling frame of this study consisted of professionals whose jobs involved the purchase of services with responsibility for designing contract agreements, managing contracts and controlling supplier performance. To increase the generalizability of the

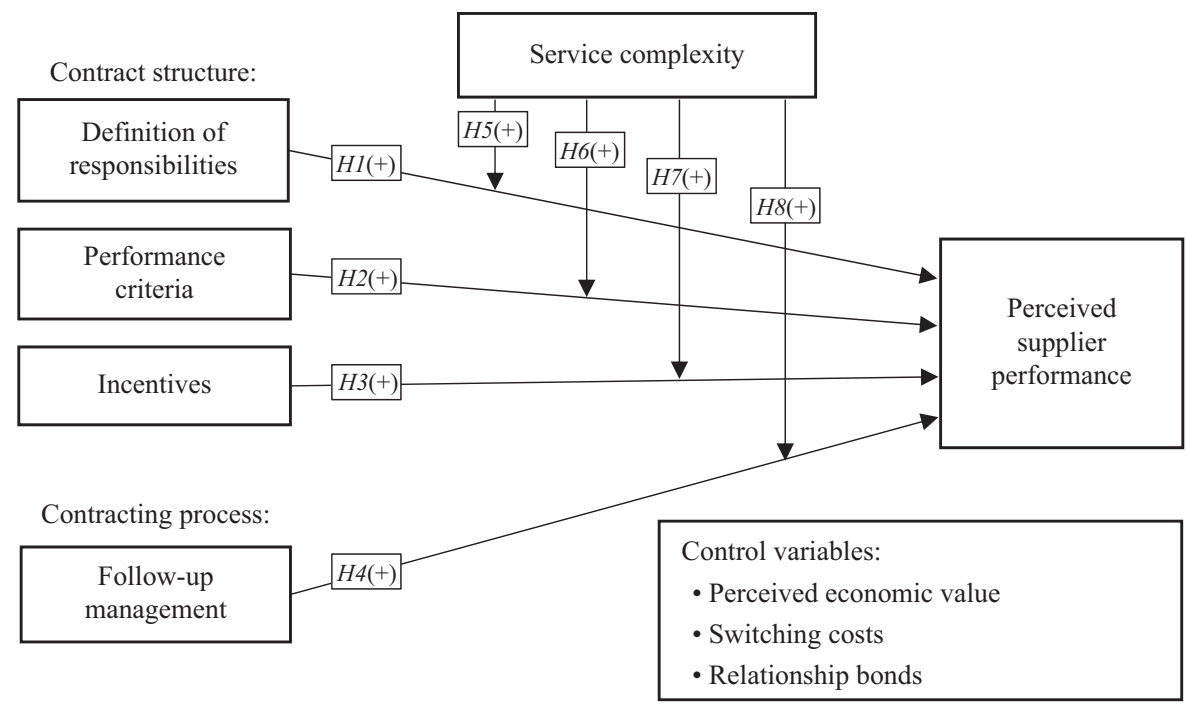

Figure 1. Research model 
IJOPM 39,4 results, we recruited respondents from around the world and from different industries, functions, and levels. LinkedIn, described as the world's largest professional network (Hutchins and Hutchins, 2016), was used to access service purchasing professionals in different countries. LinkedIn focuses on professional information, encouraging users to construct an abbreviated curriculum vitae (CV) and to establish professional connections all over the world (Skeels and Grudin, 2009). Therefore, it is informative in terms of individual and organizational profiles and can be used to enlist professionals in producing research data (Maramwidze-Merrison, 2016). The selected special interest groups of purchasing professionals are virtual online communities, where participants share knowledge, expertise and experiences in a supportive learning environment. Therefore, these groups were considered an effective way to identify and approach professionals who are involved in service purchasing. Special attention was given to the representativeness of the sample, because of the possibility that participants in professional interest groups were part of shared groups and thus were not independent.

Private focus groups on LinkedIn were used to build the contact list. These groups hold discussions among targeted groups; their membership requires an application and is controlled by the group owner, thus improving the quality of sampling over other social media. The three largest international purchasing private groups were selected as the contact database: ISM - Purchasing \& Supply Chain Manager Professionals; PMM - Purchasing \& Materials Management; and PP - Purchasing Practices. On June 30, 2015, the member counts in these three groups were $74,178,28,323$ and 14,938 , respectively.

The contact list with 1,500 names was built in two phases. First, a random sample of 1,000 names was drawn from the members visible in these three groups. Google search and company websites were used to search their e-mail addresses. If one person's e-mail address was not found on the internet, it was replaced with someone else's. Each person was sent an e-mail message containing a cover letter and the link to our web survey. Two reminder e-mails were sent during the data collection phases. After this first data collection phase (August to October 2015), 144 usable responses were received. While the results from this initial set of data were significant and later found to be almost identical[1] with the larger set of data, at this point the researchers extended their data set. The second round replicated the practices of the first round with a new set of respondents; a second contact list with 500 new names was built, and the second data collection took place from August to October 2016. The resulting data set consisted of 177 usable responses.

Thus, the combined contact list included 1,500 individuals from 46 countries. This is a non-random sample, which is a limitation of the study. However, the forums are open to anyone, and from any industry, and because of this multi-industry context and the large size of the forum groups, the members should not be more connected than people normally are in an industry.

Of the 1,500 individuals who were identified as prospects, 62 could not receive surveys because of incorrect or outdated contact information and 88 asked to be excluded from the sample (either because they were not responsible for service purchasing or because they declined to participate), resulting in an effective sample of 1,350 individuals. During these two data collection periods, 177 usable responses from 25 countries were received, for an effective response rate of 13.1 percent. A range of 6 to 16 percent is deemed acceptable (Dillman, 2000), and our results fall into this range. Most of the respondents have around ten years of purchasing experience in organizations.

\subsection{Measurement}

The multi-item scales were developed on the basis of a literature review and then refined through a series of pretests. Among the 26 indicators in Table I, 12 were adopted directly from past survey-based literature. These 12 indicators measure perceived supplier performance 


\begin{tabular}{|c|c|c|c|c|}
\hline Construct & $\begin{array}{l}\text { Item } \\
\text { name }\end{array}$ & Scale item & Adapted from & $\begin{array}{l}\text { Supplier } \\
\text { performance }\end{array}$ \\
\hline \multirow[t]{2}{*}{$\begin{array}{l}\text { Definition of } \\
\text { responsibilities }\end{array}$} & DR1 & $\begin{array}{l}\text { The responsibilities for service personnel have been } \\
\text { clearly defined in the contract }\end{array}$ & \multirow[t]{2}{*}{$\begin{array}{l}\text { Datta and Roy (2013), } \\
\text { Gruneberg et al. (2007) }\end{array}$} & \\
\hline & DR2 & $\begin{array}{l}\text { Our contract clearly defines our responsibilities as } \\
\text { the customer }\end{array}$ & & \\
\hline \multirow{2}{*}{$\begin{array}{l}\text { Performance } \\
\text { criteria }\end{array}$} & $\mathrm{PC} 1$ & Our contract clearly defines the scope of work, contract & \multirow{2}{*}{$\begin{array}{l}\text { Datta and Roy (2011), } \\
\text { Robinson and Scott } \\
\text { (2009) }\end{array}$} & 535 \\
\hline & PC2 & $\begin{array}{l}\text { terms, deliverables, and deadlines for the supplier } \\
\text { We have explicitly described service performance } \\
\text { indicators }\end{array}$ & & \\
\hline \multirow[t]{2}{*}{ Incentives } & IN1 & $\begin{array}{l}\text { Our contract includes a compensation clause in case of a } \\
\text { breach of contract }\end{array}$ & \multirow{2}{*}{$\begin{array}{l}\text { Datta and Roy (2013), } \\
\text { Robinson and Scott } \\
\text { (2009) }\end{array}$} & \\
\hline & IN2 & The contract describes how we share risks & & \\
\hline \multirow[t]{3}{*}{$\begin{array}{l}\text { Follow-up } \\
\text { management }\end{array}$} & FM1 & $\begin{array}{l}\text { We have frequent review meetings with the supplier } \\
\text { (information exchange, performance review, etc.) }\end{array}$ & \multirow{3}{*}{$\begin{array}{l}\text { Poppo and Zenger } \\
\text { (2002), Selviaridis and } \\
\text { Spring (2010) }\end{array}$} & \\
\hline & FM2 & $\begin{array}{l}\text { We revisited the service specifications in the } \\
\text { contract period }\end{array}$ & & \\
\hline & FM3 & The contract has been revised over time & & \\
\hline \multirow[t]{4}{*}{$\begin{array}{l}\text { Perceived supplier } \\
\text { performance }\end{array}$} & PSP1 & $\begin{array}{l}\text { The service provided by the supplier meets our } \\
\text { expectations }\end{array}$ & \multirow{4}{*}{$\begin{array}{l}\text { Homburg and Garbe } \\
\text { (1999), Roberts et al. } \\
\text { (2003) }\end{array}$} & \\
\hline & PSP2 & The time of service delivery meets our expectations & & \\
\hline & PSP3 & $\begin{array}{l}\text { Compared with alternative suppliers, we are confident } \\
\text { that this supplier will better help us achieve our goal }\end{array}$ & & \\
\hline & PSP4 & $\begin{array}{l}\text { We are willing to recommend the supplier without any } \\
\text { reservation }\end{array}$ & & \\
\hline \multirow[t]{6}{*}{$\begin{array}{l}\text { Service } \\
\text { complexity }\end{array}$} & & $\begin{array}{l}\text { The characteristics of the purchased service against the } \\
\text { following continuums: }\end{array}$ & \multirow{6}{*}{$\begin{array}{l}\text { Silvestro et al. (1992), } \\
\text { Stouthuysen et al. } \\
\text { (2012) }\end{array}$} & \\
\hline & $\mathrm{SC} 1$ & Peripheral (1)-important (5) & & \\
\hline & $\mathrm{SC} 2$ & Concerns a local unit (1)-concerns the whole company (5) & & \\
\hline & $\mathrm{SC} 3$ & Standardized (1)-customized (5) & & \\
\hline & $\mathrm{SC} 4$ & Generic (1)-unique to our business (5) & & \\
\hline & SC5 & Non-creative (1)-creative (5) & & \\
\hline \multirow{5}{*}{$\begin{array}{l}\text { Perceived } \\
\text { economic value } \\
\text { (control variable) } \\
\text { Switching costs } \\
\text { (control variable) }\end{array}$} & PEV1 & Service from the supplier is very economical & \multirow{5}{*}{$\begin{array}{l}\text { Barry and Terry } \\
\text { (2008), Barry and } \\
\text { Doney (2011) } \\
\text { Barry and Terry } \\
\text { (2008), Morgan and } \\
\text { Hunt (1994) }\end{array}$} & \\
\hline & PEV2 & $\begin{array}{l}\text { Service from this supplier is very good value for the } \\
\text { money }\end{array}$ & & \\
\hline & $\mathrm{SC} 1$ & $\begin{array}{l}\text { Changing the current supplier would significantly } \\
\text { increase our risks }\end{array}$ & & \\
\hline & $\mathrm{SC} 2$ & $\begin{array}{l}\text { Switching to another supplier now would make our } \\
\text { products less attractive }\end{array}$ & & \\
\hline & $\mathrm{SC} 3$ & Changing the supplier would be expensive for us & & \\
\hline \multirow{3}{*}{$\begin{array}{l}\text { Relationship } \\
\text { bonds (control } \\
\text { variable) }\end{array}$} & $\mathrm{RB} 1$ & We have a personal relationship with the supplier & \multirow{3}{*}{$\begin{array}{l}\text { Arnott et al. (2007), } \\
\text { Hennig-Thurau et al. } \\
\text { (2002) }\end{array}$} & \\
\hline & RB2 & Our relationship involves social time together & & \\
\hline & RB3 & $\begin{array}{l}\text { A strong relationship with this supplier has been } \\
\text { developed over the years }\end{array}$ & & $\begin{array}{r}\text { Operational } \\
\text { measurement scales }\end{array}$ \\
\hline
\end{tabular}

(four indicators), perceived economic value (two indicators), switching costs (three indicators) and relationship bonds (three indicators). Other indicators (definition of responsibilities, performance criteria, incentives and follow-up management) were developed using existing case studies, since no survey-based literature to measure these constructs could be found. The questionnaire was tested by a marketing researcher specialized in questionnaire design and with a sample of 18 professionals representing purchasing and business functions in private, public and non-profit organizations. These organizations cover several industries, including manufacturing, information, educational services and utilities. During the survey development, one of these pretests was run face-to-face by a practitioner from a large international company who purchases services frequently. This practitioner has worked in the 
IJOPM

39,4

536

purchasing department for eight years. She is now a global sourcing category manager responsible for purchasing travel services and some professional services in fields such as finance and accounting. She emphasized that many purchasing services decisions were made in collaboration with other functions. Therefore, we designed some questions that respondents should answer based on their most recent service-purchasing contract. The respondents who could fill in the survey indicated that they were involved in service purchasing, and their responses were included.

Both reflective and formative measurement specifications were used to capture the constructs of interest. There are three key distinctions between the two measurement specifications: the nature of the construct, the direction of causality between items and construct, and characteristics of items to measure the construct (Coltman et al., 2008). With reflective scales, commonly used in marketing research, the construct exists independent of the measured items, the direction of causality is from the construct to the measured items, and the items all share a theme and are interchangeable. However, with formative scales, the construct is a combination of its indicators, the direction of causality is from the measured items to the construct, and the items do not need to share a theme and are not expected to be correlated.

Based on these considerations, in this study, formative measurement specification was used to capture the service complexity construct. All other constructs were captured with the typical reflective view of construct specification. In this study, service complexity consists of five dimensions (shown in Table I) without a common theme. The causality is from the indicators to the construct. Therefore, it is measured on formative five-point Likert-type scales, following the five dimensions' continuums of purchased services. All other scales for reflective measures used were of the five-point Likert type, with anchors of strongly disagree (1) to strongly agree (5), as summarized in Table I. For each construct, we calculated the individual scores as mean scores of the combined scale items.

The ordinary least squares (OLS) regression model technique was chosen to test the research model. The rationale for selecting OLS is that the research model represents relationships within the underlying system that are considered to be linear. In addition, OLS enables researchers to investigate the relationships between multiple independent constructs and the dependent construct simultaneously (Ozment and Morash, 1994; Stouthuysen et al., 2012). Moreover, OLS allows for analysis of the moderating effects of service complexity on these relationships in a single research model.

\subsection{Measure validation}

Since service complexity was operationalized as a formative measure, conventional procedures would not be suitable to evaluate its reliability and validity (Diamantopoulos and Winklhofer, 2001; Stouthuysen et al., 2012). Indicator collinearity and external validity are two potential issues with formative scales (Diamantopoulos and Winklhofer, 2001). Based on the empirical study by Briggs and Grisaffe (2010), to test for these issues, we added an item to summarizing the domain of service complexity in the survey. The indicators were first regressed on this item to check for collinearity. As seen in Table II,

Table II.

Reliability and validity tests of formative construct

\begin{tabular}{llcccc}
\hline Construct & Item name & Mean & SD & VIF & Significance at $p$-value \\
\hline Service complexity & SC1 & 4.06 & 0.92 & 1.07 & $p<0.001$ \\
& SC2 & 3.55 & 1.47 & 1.09 & $p<0.001$ \\
& SC3 & 3.25 & 1.30 & 1.34 & $p<0.001$ \\
& SC4 & 2.81 & 1.29 & 1.21 & $p<0.01$ \\
& SC5 & 2.97 & 1.19 & 1.41 & $p<0.001$
\end{tabular}


the variance inflation factor (VIF) of each formative indicator was much less than 3.3, indicating that collinearity was not a problem. This means that reliability of the construct was supported. Then, to check for external validity, each indicator was correlated with the overall item. Each formative indicator was significant $(p$-value $<0.5)$ and positively related to the overall item, demonstrating that external validity was supported.

For the other reflective constructs, confirmatory factor analysis was conducted using SPSS Statistics 23.0, followed by the procedure of scale development suggested by Anderson and Gerbing (1988). As seen in Table III, all items had standardized factor loadings above 0.5 as Bagozzi and Yi (1988) suggested. The reliability test for the constructs was conducted using Cronbach's $\alpha$. Reliability values cannot be reported for the constructs (definition of responsibilities, performance criteria, incentives and perceived economic value) that only have two indicators. For other constructs the Cronbach's $\alpha$ coefficients were above 0.7 (Table III) and within the acceptable range (Fornell and Larcker, 1981). Furthermore, the average variance extracted (AVE) for each construct was above 0.5 , providing convergent validity as Fornell and Larcker (1981) recommended. Moreover, the AVE for each construct was higher than the squared correlation (shared variance) between all pairs involving the construct, supporting discriminant validity (Fornell and Larcker (1981), shown in Table IV. In summary, the results presented in Tables III and IV show that the constructs met the reliability and validity criteria.

\section{Results}

\subsection{Description of respondents}

The respondents to the survey represent experts in service purchasing within companies in a wide range of industries. Table $\mathrm{V}$ shows the demographics of the sample. The respondents come from all 18 industries in our sampling frame, which is adapted from the North American Industry Classification System, NAICS (United States Census Bureau, 2014). Moreover, as depicted in Table V, of the 177 respondents, 152 belong to the purchasing function, and 25 were from other functions, but had a strong interest in purchasing[2].

\begin{tabular}{|c|c|c|c|c|c|}
\hline Construct & Item name & Loading & Mean & $\mathrm{SD}$ & \\
\hline Definition of responsibilities & DR1 & 0.91 & 3.96 & 0.73 & \\
\hline$(\mathrm{AVE}=0.83, \alpha=\mathrm{n} / \mathrm{a})$ & DR2 & 0.91 & 3.97 & 0.71 & \\
\hline Performance criteria & $\mathrm{RC} 1$ & 0.95 & 4.05 & 0.88 & \\
\hline$(\mathrm{AVE}=0.89, \alpha=\mathrm{n} / \mathrm{a})$ & $\mathrm{RC} 2$ & 0.95 & 3.78 & 0.89 & \\
\hline Incentives & IN1 & 0.93 & 3.62 & 0.93 & \\
\hline$(\mathrm{AVE}=0.87, \alpha=\mathrm{n} / \mathrm{a})$ & IN2 & 0.93 & 3.45 & 0.88 & \\
\hline Follow-up management & FM1 & 0.90 & 3.69 & 0.82 & \\
\hline \multirow[t]{2}{*}{$(\mathrm{AVE}=0.84, \alpha=0.91)$} & FM2 & 0.93 & 3.46 & 0.78 & \\
\hline & FM3 & 0.93 & 3.33 & 0.82 & \\
\hline Perceived supplier performance & PSP1 & 0.90 & 3.88 & 0.66 & \\
\hline \multirow[t]{3}{*}{$(\mathrm{AVE}=0.75, \alpha=0.89)$} & PSP2 & 0.88 & 3.84 & 0.66 & \\
\hline & PSP3 & 0.85 & 3.76 & 0.71 & \\
\hline & PSP4 & 0.85 & 3.56 & 0.76 & \\
\hline Perceived economic value & PEV1 & 0.92 & 3.49 & 0.75 & \\
\hline$(\mathrm{AVE}=0.84, \alpha=\mathrm{n} / \mathrm{a})$ & PEV2 & 0.92 & 3.66 & 0.75 & \\
\hline Switching costs & $\mathrm{SC} 1$ & 0.89 & 3.21 & 1.01 & \\
\hline \multirow[t]{2}{*}{$(\mathrm{AVE}=0.79, \alpha=0.87)$} & $\mathrm{SC} 2$ & 0.88 & 2.82 & 0.86 & \\
\hline & SC3 & 0.91 & 3.15 & 0.97 & Table III. \\
\hline Relationship bonds & $\mathrm{RB} 1$ & 0.92 & 3.06 & 0.92 & Construct and \\
\hline \multirow[t]{2}{*}{$(\mathrm{AVE}=0.83, \alpha=0.90)$} & RB2 & 0.92 & 2.79 & 0.88 & reflective measure \\
\hline & RB3 & 0.90 & 3.12 & 0.97 & analysis \\
\hline
\end{tabular}


IJOPM

39,4

538

Table IV

Discriminant validity test from average variance extracted

\begin{tabular}{|c|c|c|c|c|c|c|c|c|}
\hline Construct & 1 & 2 & 3 & 4 & 5 & 6 & 7 & 8 \\
\hline 1. Definition of responsibilities & 0.83 & & & & & & & \\
\hline 2. Performance criteria & $0.06^{* * *}$ & 0.89 & & & & & & \\
\hline 3. Incentives & $0.07^{* * *}$ & $0.10 * *$ & 0.87 & & & & & \\
\hline 4. Follow-up management & $0.06^{* * *}$ & 0.00 & $0.15^{*}$ & 0.84 & & & & \\
\hline 5. Perceived supplier performance & $0.20 * *$ & $0.33^{* *}$ & $0.35 * *$ & $0.14^{* *}$ & 0.75 & & & \\
\hline 6. Perceived economic value & $0.06^{* * *}$ & $0.10^{* *}$ & $0.05^{* *}$ & 0.02 & $0.12^{* *}$ & 0.84 & & \\
\hline 7. Switching costs & 0.01 & 0.00 & 0.07 & 0.01 & 0.01 & 0.01 & 0.79 & \\
\hline 8. Relationship bonds & 0.03 & $0.03 * *$ & $0.06 * *$ & $0.10 * *$ & $0.10 * *$ & 0.02 & $0.03^{* *}$ & 0.8 \\
\hline
\end{tabular}

Notes: The average variances extracted by the construct are shown on the diagonal, while the off-diagonal entries show the squared correlation between constructs, as Fornell and Larcker (1981) suggested. ${ }^{*} p<0.05$; $* * p<0.01$

\begin{tabular}{|c|c|c|c|c|}
\hline Position in the firm & $\begin{array}{l}\text { Purchasing } \\
\text { function }\end{array}$ & $\begin{array}{l}\text { Any other } \\
\text { function }\end{array}$ & Total number & Percentage \\
\hline Executive & 6 & 8 & 14 & 7.91 \\
\hline SVP or VP & 17 & 3 & 20 & 11.30 \\
\hline Director & 43 & 5 & 48 & 27.12 \\
\hline Manager or team leader & 67 & 4 & 71 & 40.11 \\
\hline Expert, specialist, or consultant & 18 & 5 & 23 & 12.99 \\
\hline Assistant or coordinator & 1 & 0 & 1 & 0.56 \\
\hline Total & $152(85.88 \%)$ & $25(14.12 \%)$ & 177 & 100 \\
\hline Average purchasing experience (years) & 13.4 & 12.9 & 13.4 & \\
\hline \multicolumn{3}{|l|}{ Industry } & $\begin{array}{l}\text { Number of } \\
\text { respondents }\end{array}$ & Percentage \\
\hline \multicolumn{3}{|l|}{ Accommodation and food services } & 5 & 2.82 \\
\hline \multicolumn{3}{|l|}{ Agriculture, forestry, fishing and hunting } & 4 & 2.26 \\
\hline \multicolumn{3}{|l|}{ Accommodation and food services } & 1 & 0.56 \\
\hline \multicolumn{3}{|l|}{ Construction } & 4 & 2.26 \\
\hline \multicolumn{3}{|l|}{ Educational services } & 3 & 1.69 \\
\hline \multicolumn{3}{|l|}{ Finance and insurance } & 5 & 2.82 \\
\hline \multicolumn{3}{|l|}{ Health care and social assistance } & 17 & 9.60 \\
\hline \multicolumn{3}{|c|}{ Information (publishing, telecommunications, all information services) } & 14 & 7.91 \\
\hline \multicolumn{3}{|l|}{ Manufacturing } & 71 & 40.11 \\
\hline \multicolumn{3}{|l|}{ Mining, quarrying, and oil and gas extraction } & 4 & 2.26 \\
\hline \multicolumn{3}{|l|}{ Other services (except public administration) } & 11 & 6.21 \\
\hline \multicolumn{3}{|l|}{ Professional, scientific and technical services } & 15 & 8.47 \\
\hline \multicolumn{3}{|l|}{ Public administration } & 3 & 1.69 \\
\hline \multicolumn{3}{|l|}{ Real estate and rental and leasing } & 1 & 0.56 \\
\hline \multicolumn{3}{|l|}{ Retail trade } & 7 & 3.95 \\
\hline \multicolumn{3}{|l|}{ Transportation and warehousing } & 4 & 2.26 \\
\hline \multicolumn{3}{|l|}{ Utilities (power, gas, water, sewage, etc.) } & 7 & 3.95 \\
\hline \multicolumn{3}{|l|}{ Wholesale trade } & 1 & 0.56 \\
\hline \multicolumn{3}{|l|}{ Total (18) } & 177 & 100.00 \\
\hline
\end{tabular}

Most of the 152 respondents from the purchasing function were middle- or senior-level purchasing managers within their organizations. The respondents' extensive experience in the purchasing profession makes their answers valuable and relevant to the survey. The average experience of the respondents in the purchasing function was 13.4 years and 12.9 years for those in other functions. 


\subsection{Results of testing hypotheses}

The hypotheses were tested with two OLS regression models. Model 1 was estimated to test $H 1-H 4$. Model 2 was estimated to test the moderating influences $-H 5-H 8$. The regression diagnostics procedures suggested by Hair et al. (2006) were followed. The final statistical results for two regression models are summarized in Table VI. $R^{2}$ and adjusted $R^{2}$ are also shown, illustrating that these two models are statistically significant.

The regression results of model 1 , reported in Table VI, reveal that $H 1-H 4$ were supported by the data. Specifically, the definition of responsibilities, performance criteria and incentives designed in service contracts had significant positive impacts on perceived supplier performance, supporting $H 1(\beta=0.17, p<0.001), H 2(\beta=0.25, p<0.001)$ and $H 3$ $(\beta=0.24, p<0.001)$, respectively. Similarly, support was shown for the impact that a buyer's follow-up management of a contracting process had on perceived supplier performance $(\beta=0.18, p<0.001)$. These results indicate that both the contract structure and the process can drive supplier performance. Furthermore, according to the Chow test (Chow, 1960), the independent variable with the greater coefficient has a greater impact on the dependent variable. Therefore, based on the coefficients, the effects of performance criteria $(\beta=0.25)$ and incentives $(\beta=0.24)$ designed in service contracts on perceived supplier performance were a little bit greater than the effects of definition of responsibilities defined in service contracts $(\beta=0.17)$ and a buyer's follow-up management of a contracting process $(\beta=0.18)$. These findings show that in terms of supplier performance perceived by the buyer, performance criteria and incentives designed in service contracts are generally more important indicators than the definition of responsibilities and a buyer's follow-up management of a contracting process.

As seen in model 2 , for $H 5$, the proposed moderation had the only nonsignificant effects, since the $p$-value was greater than 0.05 . This implies that $H 5$ was rejected $(\beta=-0.01$, $p>0.05)$. For $H 6$, the influence of performance defined in the contract on perceived supplier

\begin{tabular}{|c|c|c|c|c|c|}
\hline & Depe & variable: $\mathrm{p}$ & $\mathrm{d}$ supplier $\mathrm{p}$ & & \\
\hline & & & & & \\
\hline & Coefficient & $t$-value & Coefficient & $t$-value & \\
\hline Main effects & & & & & \\
\hline Definition of responsibility (DR) & 0.17 & $3.78 * * *$ & 0.12 & $2.72 * *$ & \\
\hline Performance criteria (PC) & 0.25 & $7.14 * * *$ & 0.25 & $7.15^{* * * *}$ & \\
\hline Incentives (IN) & 0.24 & $6.77 * * *$ & 0.22 & $6.39 * * *$ & \\
\hline Follow-up management (FM) & 0.18 & $4.72 * * *$ & 0.18 & $4.92^{* * * *}$ & \\
\hline Service complexity (SC) & & & 0.06 & 1.54 & \\
\hline Interaction terms & & & & & \\
\hline $\mathrm{DR} \times \mathrm{SC}$ & & & -0.01 & -0.41 & \\
\hline $\mathrm{PC} \times \mathrm{SC}$ & & & -0.07 & $-2.52^{*}$ & \\
\hline $\mathrm{IN} \times \mathrm{SC}$ & & & 0.06 & $2.79 * *$ & \\
\hline $\mathrm{FM} \times \mathrm{SC}$ & & & 0.06 & $2.54^{*}$ & \\
\hline Control variables & & & & & \\
\hline Perceived economic value & 0.11 & $2.70 * *$ & 0.08 & $2.03^{*}$ & \\
\hline Switching costs & 0.03 & 0.92 & 0.02 & 0.52 & \\
\hline Relationship bonds & 0.05 & 1.31 & 0.02 & 0.77 & \\
\hline Model fit & & & & & \\
\hline & 0.66 & & 0.70 & & \\
\hline Adjusted $R^{2}$ & 0.65 & & 0.68 & & Table VI. \\
\hline$F$-statistic & $46.61^{* * * *}$ & & $32.62 * * *$ & & OLS results for \\
\hline Notes: $* p<0.05 ; * * p<0.01 ; * * *$ & .001 & & & & hypothesized effects \\
\hline
\end{tabular}


IJOPM

39,4

540

performance was significantly diminished at higher levels of service complexity $(\beta=-0.07$, $p<0.05$ ). This finding was the reverse of $H 6$, implying that $H 6$ was not supported. However, in support of $H 7$, the influence of incentives defined in the contract on perceived supplier performance was significantly stronger at higher levels of service complexity $(\beta=0.06, p<0.01)$. Furthermore, the test of $H 8$ was supported. Service complexity was a significant moderator, with higher levels of service complexity magnifying the impact of the buyer's follow-up management on perceived supplier performance $(\beta=0.06, p<0.05)$. Consequently, service complexity significantly increased the effects of incentives and follow-up management on perceived supplier performance but significantly decreased the effects of performance criteria defined in the contract on perceived supplier performance.

\section{Discussion}

\subsection{The effects of contract structure on perceived supplier performance}

The service complexity increases risks and uncertainty in service delivery. Hence, organizations seek effective ways to manage the performance of their service suppliers. Our findings reveal that all three dimensions of contract structure have positive impacts on perceived supplier performance. The literature demonstrates that designing contract structure is crucial for successful B2B service deliveries (Selviaridis and Spring, 2010; Van Der Valk and van Iwaarden, 2011), but empirical work examining the structure of service contracts between buyers and suppliers that influence the supplier performance has remained scant. The statistical results in this study validate the findings identified in previous case studies (Datta and Roy, 2011, 2013; Robinson and Scott, 2009), which suggest that the definition of responsibilities, performance indicators and incentives should be stipulated in the contract to ensure effective service delivery. Therefore, the findings support the TCE theory that suggests that drafting a detailed contract mitigates opportunism (Williamson, 1985) and illustrate the theory's relevance in designing the B2B service contract.

The three dimensions addressing opportunism arising from asset specificity and measurement difficulty can be considered as three performance-enhancing aspects of designing the service contract. This provides a basis for buyers to design a service contract to ensure effective service delivery. A contract structure designing these three dimensions could give suppliers a better understanding of the ways of delivering the performance that the buyers require. A large body of service literature emphasizes the importance of contractual governance for effective service delivery (Enquist et al., 2011; Roehrich and Lewis, 2014; Van Der Valk et al., 2016). Our results provide knowledge on the development of contractual governance for improving the supplier performance, indicating that the three dimensions should be carefully formulated in the contracts. Taking these contract dimensions as guidelines helps buyers define contract terms and agreements for contractual governance and thus motivates suppliers to achieve the target level of performance.

\subsection{The effects of the contracting process}

Our findings demonstrate that the buyer's follow-up management practices in a contracting process have positive impacts on perceived supplier performance. These practices are designed to reduce the exchange hazards of uncertainty, which follows TCE logic. This indicates that contracts that are designed in line with transaction costs minimization can achieve good service performance (Susarla et al., 2009). These practices consist of establishing frequent review meetings between buyers and service providers, revisiting service specifications throughout the contracting period, and revising the contract if necessary to facilitate adaptation to the service and exchange relationship. These practices contribute to the TCE theory by translating what effective contractual governance practices can be for services. The management practices in a contracting process are efficient ways to 
respond to unexpected contingencies that may arise during the course of the contract. The statistical results in this study are consistent with previous case studies on management of a contracting process (Roehrich and Lewis, 2010; Selviaridis and Spring, 2010; Zheng et al., 2008). For example, Selviaridis and Spring (2010) found that when firms purchase complex services, establishing a review system in the contracting process is important. These followup management practices can be recognized as useful instruments to control opportunism and nourish cooperation for ensuring good service deliveries.

\subsection{The moderating effects of service complexity}

The present study shows that service complexity has a significant moderating effect on the relationship between incentives designed in the contract and perceived supplier performance. This result indicates that the more complex the service is, the greater the role of incentives in achieving good supplier performance. As the complexity of services enhances difficulties in service specification and then increases risks for buyers to purchase it, incentives including risk sharing can better align two parties and motivate them to work together to achieve better performance. These results provide the statistical evidence on the findings in the case study by Datta and Roy (2013), which reported that incentives designed in the contracts could lead to high supplier performance in terms of purchasing complex services. Therefore, the incentive structure helps the buyer succeed in purchasing complex services.

Furthermore, service complexity was found to have a significant moderating effect on the relationship between the buyer's follow-up management in the contracting process and perceived supplier performance, effectively raising the importance of contract management practices in purchasing complex services. Service complexity increases difficulties in service specification and makes these contingencies more likely. The buyer's follow-up management enables the two parties to adapt to reasonable changes, thereby enhancing supplier performance.

However, the results indicate that service complexity reduces the effect of performance criteria defined in the contract on supplier performance, which is contradictory to H6. The expected closer association between performance criteria and supplier performance appears under the conditions of low, rather than high service complexity. The authors assumed that when the complexity of purchased service is high, uncertainty and role ambiguity are increased, and thus more-detailed performance criteria are required to address such uncertainty based on TCE and previous empirical studies. However, performance criteria defined in the contract fail to improve supplier performance when uncertainty is extremely high because it no long cannot function as an effective safeguard mechanism, as suggested in TCE (Williamson, 1991). TCE takes a static view to contract design ( $\mathrm{Zu}$ and Kaynak, 2012), the initial performance indicators identified in a service contract might be inefficient during the contracting process (Aarikka-Stenroos and Jaakkola, 2012; Powers et al., 2016). This would increase the difficulty of controlling and monitoring the contract, which encourages a supplier's opportunistic behavior and weakens its performance. Under such circumstances, buyers are willing to accept less-precise performance criteria in the formal contract and adjust it to unforeseen contingencies during the contracting process. This yields new evidence that the complexity of services increases the importance of the buyer's follow-up management practices to attain the desired service performance. This is in line with the recent study by Selviaridis and Spring (2018), which illustrated the processual approach of contracting as parties learn about inefficiencies related to performance indicators and adjust them. This, in turn, improves their mutual understanding and alignment of performance objectives and incentives. Therefore, when service complexity is high, it is unlikely to employ defined performance criteria to enhance supplier performance since criteria need to be constantly revisited and redesigned in the contracting process. 
IJOPM

39,4

542

In addition, the current findings cannot confirm the moderating effect of service complexity on the relationship between the definition of responsibilities and perceived supplier performance (H5). Departing from a static view of TCE, the characteristics of extremely complex services, such as uncertainty and customization, drive the involved parties to adjust the definition of responsibilities during the contracting process. Too detailed specifications reduce flexibility among the parties, which then decreases the willingness of parties to change their behavior to achieve an agreed-upon level of performance (Huo et al., 2016). Therefore, the results highlight the importance of post-contract management practices in purchasing complex services, indicating the need for sufficient information systems integration between the parties in order to reduce information asymmetry. Besides, as expressed by previous studies, contractual governance is an important way to constrain opportunistic behaviors and influence supplier performance (Kreye et al., 2015; Poppo and Zenger, 2002). In addition, contractual governance can be supported by informal relational governance mechanisms such as building trust and commitment (Krishnan et al., 2016).

\section{Conclusions}

This study examines the effects of contract structure and follow-up management on supplier performance from the perspective of TCE in the context of global B2B services. It also investigates the moderating effects of service complexity in these relationships. In so doing, the present study extends the explanatory power of TCE by developing and empirically testing a research model that covers essential aspects of service contracting structure and the contracting process. Based on an analysis of data collected from 177 purchasing professionals in 25 countries, the study makes four contributions to the literature of service purchasing.

First, it extends the knowledge about performance-enhancing aspects of designing the service contract between buyers and service providers. This study synthesizes existing knowledge to develop and apply a research model for examining the effects of designing contract structure and managing a contracting process on perceived supplier performance across a wide range of industries and countries. Second, this study generates knowledge about monitoring the incomplete service contract through a contracting process to enhance supplier performance. Third, the study explores the role of service complexity in purchasing B2B services. Although service complexity is not a new construct in the service literature, few studies have investigated its influence on B2B service purchasing. Finally, as a methodological contribution, the present study shows that LinkedIn contact databases can be used to identify suitable respondents across different countries. This has not yet been shown in the literature. The lesson to be learned from the process of data collection in this study is that LinkedIn focus groups can be harnessed to build a sample list. This suggests that social scientists should pay more attention to new databases of business professionals, such as LinkedIn.

\subsection{Managerial implications}

The study has two implications for B2B service purchasing professionals. The results suggest that purchasing managers should specify service contents, set performance indicators, describe responsibilities and shared risks in the contract, and monitor the contract through the entire service delivery process to secure good performance from the supplier. Our findings might be more important for companies that have just begun shifting from buying goods to buying services because conventional supply contracts are not suitable for purchasing services. The framework and guidelines from this study can assist these companies in arriving at a better understanding of the influences of contract design and management of the contracting process for the service supplier's improved performance.

The second implication is that the moderating results show that service complexity increases the importance of incentives and follow-up management to obtain the desired service performance. This finding indicates that when companies purchase more complex 
services, they should also pay more attention to designing incentives in the contract and developing comprehensive review processes for contract management. In addition, the study may have wider implications for the evolution of service purchasing. A better understanding of how firms can accommodate the complexity of service transactions may improve the productivity of all service-intensive industries.

\subsection{Limitations and future research}

The present study has several limitations that can be addressed in future research. One limitation pertains to the survey scale items. As for three major dimensions of contract structure, each construct only consisted of two items, which may have weakened construct validity. In further studies, researchers are encouraged to investigate the model by exploring other observed variables related to these constructs.

The limitation related to a generalization of the results should also be noted. The sample of the study was not selected entirely at random. Although the 1,500 people on the contact list were randomly selected from three purchasing groups on LinkedIn, membership in these purchasing groups was not random. Also, although the collected data in this study came from 25 countries, the countries were not equally represented, so the results cannot be generalized. Therefore, to arrive at more generalizable results, we recommend that future research test the research model in a larger and more comprehensive sample of industries and countries.

Finally, other variables beyond the scope of the investigation may be important in B2B services. Other variables included in the study may statistically rule out other confounds or sources contributing to the examined relationships. For instance, services, especially complex services, are built on intangible qualities and dependent on interaction (Axelsson and Wynstra, 2002; Van Der Valk and Rozemeijer, 2009) and thus may be influenced by buyer behavior (Ramsay et al., 2013). These characteristics may make buyer-perceived supplier performance sensitive to differences in culture since they are subjective and depend on the customer's perceptions. Therefore, cultural differences may have meaningful relationships with perceived supplier performance. Although the aim of this study was to examine contract design and management practices in relation to perceived supplier performance, future studies can consider a more comprehensive set of determinants in supplier performance. In addition, although we controlled for perceived economic value, switching cost, and buyersupplier relationship bonds, future studies should incorporate a more extensive set of firmspecific control variables such as firm revenue and age of relationship.

\section{Notes}

1. The confirmed hypotheses with initial data set $(n=144)$ are also supported by the larger data set $(n=177)$ respondents. The biggest difference in the coefficients of all confirmed relationships is less than 0.01 . The researchers, thus, chose to use the larger set of data.

2. The group of 152 respondents representing the purchasing function was compared against the whole group of 177 respondents from the purchasing and non-purchasing functions. The largest difference in the coefficient between the two groups for all the tested relationships was 0.01, making no difference in the results. Thus, the researchers chose to include the respondents from non-purchasing function in the study.

\section{References}

Aarikka-Stenroos, L. and Jaakkola, E. (2012), "Value co-creation in knowledge intensive business services: a dyadic perspective on the joint problem solving process", Industrial Marketing Management, Vol. 41 No. 1, pp. 15-26.

Anderson, J.C. and Gerbing, D.W. (1988), "Structural equation modeling in practice: a review and recommended two-step approach”, Psychological Bulletin, Vol. 103 No. 3, pp. 411-423. 
IJOPM

39,4

Anderson, S.W. and Dekker, H.C. (2005), "Management control for market transactions: the relation between transaction characteristics, incomplete contract design, and subsequent performance", Management Science, Vol. 51 No. 12, pp. 1734-1752.

Apte, U.M. and Vepsäläinen, A.P. (1993), "High tech or high touch? Efficient channel strategies for delivering financial services", The Journal of Strategic Information Systems, Vol. 2 No. 1, pp. 39-54.

Arnott, D.C., Wilson, D., Doney, P.M., Barry, J.M. and Abratt, R. (2007), "Trust determinants and outcomes in global B2B services", European Journal of Marketing, Vol. 41 Nos 9/10, pp. 1096-1116.

Axelsson, B. and Wynstra, F. (2002), Buying Business Services, John Wiley, New York, NY.

Ayala, N.F., Gerstlberger, W. and Frank, A.G. (2019), "Managing servitization in product companies: the moderating role of service suppliers", International Journal of Operations \& Production Management, Vol. 39 No. 1, pp. 43-74.

Azarenko, A., Roy, R., Shehab, E. and Tiwari, A. (2009), "Technical product-service systems: some implications for the machine tool industry", Journal of Manufacturing Technology Management, Vol. 20 No. 5, pp. 700-722.

Bagozzi, R.P. and Yi, Y. (1988), "On the evaluation of structural equation models", Journal of the Academy of Marketing Science, Vol. 16 No. 1, pp. 74-94.

Baines, T., Lightfoot, H. and Smart, P. (2011), "Servitization within manufacturing: exploring the provision of advanced services and their impact on vertical integration", Journal of Manufacturing Technology Management, Vol. 22 No. 7, pp. 947-954.

Barry, J. and Terry, T.S. (2008), "Empirical study of relationship value in industrial services", Journal of Business and Industrial Marketing, Vol. 23 No. 4, pp. 228-241.

Barry, J.M. and Doney, P.M. (2011), "Cross-cultural examination of relationship quality”, Journal of Global Marketing, Vol. 24 No. 4, pp. 305-323.

Bastl, M., Johnson, M., Lightfoot, H. and Evans, S. (2012), "Buyer-supplier relationships in a servitized environment: an examination with Cannon and Perreault's framework", International Journal of Operations and Production Management, Vol. 32 No. 6, pp. 650-675.

Benedettini, O. and Neely, A. (2012), "Factors influencing service complexity: the perspective of servitized manufacturers", International Annual European Operations Management Association Conference, pp. 1-5.

Brax, S.A. and Jonsson, K. (2009), "Developing integrated solution offerings for remote diagnostics: a comparative case study of two manufacturers", International Journal of Operations \& Production Management, Vol. 29 No. 5, pp. 539-560.

Brax, S.A., Bask, A., Hsuan, J. and Voss, C. (2017), "Service modularity and architecture-an overview and research agenda", International Journal of Operations \& Production Management, Vol. 37 No. 6, pp. 686-702.

Briggs, E. and Grisaffe, D. (2010), "Service performance - loyalty intentions link in a business-to-business context: the role of relational exchange outcomes and customer characteristics", Journal of Service Research, Vol. 13 No. 1, pp. 37-51.

Broekhuis, M. and Scholten, K. (2018), "Purchasing in service triads: the influence of contracting on contract management", International Journal of Operations \& Production Management, Vol. 38 No. 5, pp. 1188-1204.

Brown, T.L., Potoski, M. and Van Slyke, D.M. (2006), "Managing public service contracts: aligning values, institutions, and markets", Public Administration Review, Vol. 66 No. 3, pp. 323-331.

Cannon, J.P., Achrol, R.S. and Gundlach, G.T. (2000), "Contracts, norms, and plural form governance", Journal of the Academy of Marketing Science, Vol. 28 No. 2, pp. 180-194.

Cao, Z. and Lumineau, F. (2015), "Revisiting the interplay between contractual and relational governance: a qualitative and meta-analytic investigation", Journal of Operations Management, Vol. 33, pp. 15-42. 
Carter, R. and Hodgson, G.M. (2006), "The impact of empirical tests of transaction cost economics on the debate on the nature of the firm", Strategic Management Journal, Vol. 27 No. 5, pp. 461-476.

Chang, Y.B., Gurbaxani, V. and Ravindran, K. (2017), "Information technology outsourcing: asset transfer and the role of contract", MIS Quarterly: Management Information Systems, Vol. 41 No. 3, pp. 959-973.

Chow, G.C. (1960), "Tests of equality between sets of coefficients in two linear regressions", Econometrica: Journal of the Econometric Society, Vol. 28 No. 3, pp. 591-605.

Coltman, T., Devinney, T.M., Midgley, D.F. and Venaik, S. (2008), "Formative versus reflective measurement models: two applications of formative measurement", Journal of Business Research, Vol. 61 No. 12, pp. 1250-1262.

Cousins, P.D., Lawson, B. and Squire, B. (2008), "Performance measurement in strategic buyer-supplier relationships: the mediating role of socialization mechanisms", International Journal of Operations \& Production Management, Vol. 28 No. 3, pp. 238-258.

Datta, P.P. and Roy, R. (2011), "Operations strategy for the effective delivery of integrated industrial product-service offerings: two exploratory defence industry case studies", International Journal of Operations and Production Management, Vol. 31 No. 5, pp. 579-603.

Datta, P.P. and Roy, R. (2013), "Incentive issues in performance-based outsourcing contracts in the UK defence industry: a simulation study", Production Planning and Control, Vol. 24 Nos 4/5, pp. 359-374.

Diamantopoulos, A. and Winklhofer, H.M. (2001), "Index construction with formative indicators: an alternative to scale development", Journal of Marketing Research, Vol. 38 No. 2, pp. 269-277.

Dillman, D.A. (2000), Mail and Internet Surveys: The Tailored Design Method, Wiley, New York, NY.

Donato, R. (2010), "Extending transaction cost economics: towards a synthesised approach for analysing contracting in health care markets with experience from the Australian private sector”, Social Science \& Medicine, Vol. 71 No. 11, pp. 1989-1996.

Ellram, L.M., Tate, W.L. and Billington, C. (2008), "Offshore outsourcing of professional services: a transaction cost economics perspective", Journal of Operations Management, Vol. 26 No. 2, pp. 148-163.

Enquist, B., Camén, C. and Johnson, M. (2011), "Contractual governance for public service value networks", Journal of Service Management, Vol. 22 No. 2, pp. 217-240.

Faems, D., Janssens, M., Madhok, A. and Looy, B.V. (2008), "Toward an integrative perspective on alliance governance: connecting contract design, trust dynamics, and contract application", Academy of Management Journal, Vol. 51 No. 6, pp. 1053-1078.

Ferguson, R.J., Paulin, M. and Bergeron, J. (2005), "Contractual governance, relational governance, and the performance of interfirm service exchanges: the influence of boundary-spanner closeness", Journal of the Academy of Marketing Science, Vol. 33 No. 2, pp. 217-234.

Flint, D.J., Blocker, C.P. and Boutin, P.J. (2011), "Customer value anticipation, customer satisfaction and loyalty: an empirical examination”, Industrial Marketing Management, Vol. 40 No. 2, pp. 219-230.

Fornell, C. and Larcker, D.F. (1981), "Evaluating structural equation models with unobservable variables and measurement error", Journal of Marketing Research, Vol. 18 No. 1, pp. 39-50.

Forza, C. (2002), "Survey research in operations management: a process-based perspective", International Journal of Operations \& Production Management, Vol. 22 No. 2, pp. 152-194.

Gao, N., Chen, Y., Wang, W. and Wang, Y. (2018), "Addressing project complexity: the role of contractual functions", Journal of Management in Engineering, Vol. 34 No. 3, pp. 1-12.

Grubic, T. and Jennions, I. (2017), "Remote monitoring technology and servitised strategies-factors characterising the organisational application”, International Journal of Production Research, Vol. 56 No. 6, pp. 1-17.

Gruneberg, S., Hughes, W. and Ancell, D. (2007), "Risk under performance-based contracting in the UK construction sector”, Construction Management and Economics, Vol. 25 No. 7, pp. 691-699. 
IJOPM

39,4

Hair, J.F., Black, W.C., Babin, B.J., Anderson, R.E. and Tatham, R.L. (2006), Multivariate Data Analysis, Pearson Prentice Hall, Upper Saddle River, NJ.

Handley, S.M. and Benton, W.C. Jr (2013), "The influence of task- and location-specific complexity on the control and coordination costs in global outsourcing relationships", Journal of Operations Management, Vol. 31 No. 3, pp. 109-128.

Heikkilä, J., Vuori, M. and Laine, J.A.T. (2013), Purchasing Business Services, The Federation of Finnish Technology Industries, Helsinki.

Hennig-Thurau, T., Gwinner, K.P. and Gremler, D.D. (2002), "Understanding relationship marketing outcomes an integration of relational benefits and relationship quality", Journal of Service Research, Vol. 4 No. 3, pp. 230-247.

Homburg, C. and Garbe, B. (1999), "Towards an improved understanding of industrial services: quality dimensions and their impact on buyer-seller relationships", Journal of Business-to-Business Marketing, Vol. 6 No. 2, pp. 39-71.

Huo, B., Fu, D., Zhao, X. and Zhu, J. (2016), "Curbing opportunism in logistics outsourcing relationships: the role of relational norms and contract", International Journal of Production Economics, Vol. 182, pp. 293-303.

Hutchins, A.L. and Hutchins, A.L. (2016), "Beyond resumes: LinkedIn for marketing educators”, Journal of Research in Interactive Marketing, Vol. 10 No. 2, pp. 137-147.

Jensen, M.C. and Meckling, W.H. (1995), "Specific and general knowledge and organizational structure", Journal of Applied Corporate Finance, Vol. 8 No. 2, pp. 4-12.

Johnston, D.A., Mccutcheon, D.M., Stuart, F.I. and Kerwood, H. (2004), "Effects of supplier trust on performance of cooperative supplier relationships", Journal of Operations Management, Vol. 22 No. 1, pp. 23-38.

Kleemann, F.C. and Essig, M. (2013), “A provider's perspective on supplier relationships in performance-based contracting", Journal of Purchasing and Supply Management, Vol. 19 No. 3, pp. 185-198.

Kreye, M.E. (2019), "Does a more complex service offering increase uncertainty in operations?", International Journal of Operations \& Production Management, Vol. 39 No. 1, pp. 75-93.

Kreye, M.E., Newnes, L.B. and Goh, Y.M. (2014), “Uncertainty in competitive bidding-a framework for product-service systems", Production Planning \& Control, Vol. 25 No. 6, pp. 462-477.

Kreye, M.E., Roehrich, J.K. and Lewis, M.A. (2015), "Servitising manufacturers: the impact of service complexity and contractual and relational capabilities", Production Planning and Control, Vol. 26 Nos 14/15, pp. 1233-1246.

Krishnan, R., Geyskens, I. and Steenkamp, J.B.E. (2016), "The effectiveness of contractual and trustbased governance in strategic alliances under behavioral and environmental uncertainty", Strategic Management Journal, Vol. 37 No. 12, pp. 2521-2542.

Larsen, M.M., Manning, S. and Pedersen, T. (2013), "Uncovering the hidden costs of offshoring: the interplay of complexity, organizational design, and experience", Strategic Management Journal, Vol. 34 No. 5 , pp. 533-552.

Li, Y., Xie, E., Teo, H.H. and Peng, M.W. (2010), "Formal control and social control in domestic and international buyer-supplier relationships", Journal of Operations Management, Vol. 28 No. 4, pp. 333-344.

Liu, Y., Luo, Y. and Liu, T. (2009), "Governing buyer-supplier relationships through transactional and relational mechanisms: evidence from China”, Journal of Operations Management, Vol. 27 No. 4, pp. 294-309.

Lonsdale, C. (2001), "Locked-ln to supplier dominance: on the dangers of asset specificity for the outsourcing decision", Journal of Supply Chain Management, Vol. 37 No. 1, pp. 22-27.

Lui, S.S. and Ngo, H.-Y. (2004), "The role of trust and contractual safeguards on cooperation in non-equity alliances", Journal of Management, Vol. 30 No. 4, pp. 471-485. 
Lyons, B. and Mehta, J. (1997), "Contracts, opportunism and trust: self-interest and social orientation", Cambridge Journal of Economics, Vol. 21 No. 2, pp. 239-257.

Mcdougall, G.H. and Levesque, T. (2000), "Customer satisfaction with services: putting perceived value into the equation", Journal of Services Marketing, Vol. 14 No. 5, pp. 392-410.

Malatesta, D. and Smith, C. (2014), "Designing contracts for complex services", Public Administration, Vol. 92 No. 3, pp. 531-548.

Malhotra, D. and Lumineau, F. (2011), "Trust and collaboration in the aftermath of conflict: the effects of contract structure", Academy of Management Journal, Vol. 54 No. 5, pp. 981-998.

Maramwidze-Merrison, E. (2016), "Innovative methodologies in qualitative research: social media window for accessing organisational elites for interviews", Electronic Journal of Business Research Methods, Vol. 14 No. 2, pp. 1-11.

Mills, J., Purchase, V.C. and Parry, G. (2013), "Enterprise imaging: representing complex multi-organizational service enterprises", International Journal of Operations \& Production Management, Vol. 33 No. 2, pp. 159-180.

Modi, S.B. and Mabert, V.A. (2007), "Supplier development: improving supplier performance through knowledge transfer", Journal of Operations Management, Vol. 25 No. 1, pp. 42-64.

Moorman, C., Zaltman, G. and Deshpande, R. (1992), "Relationships between providers and users of marketing research: the nature of trust within and between organizations", Journal of Marketing Research, Vol. 29 No. 3, pp. 404-409.

Morgan, R.M. and Hunt, S.D. (1994), "The commitment-trust theory of relationship marketing”, Journal of Marketing, Vol. 58 No. 3, pp. 20-38.

Nakos, G. and Brouthers, K.D. (2008), "International alliance commitment and performance of small and medium-size enterprises: the mediating role of process control", Journal of International Management, Vol. 14 No. 2, pp. 124-137.

Narayanan, V. and Raman, A. (2004), "Aligning incentives in supply chains”, Harvard Business Review, Vol. 82 No. 11, pp. 94-102, 149.

Ng, I.C., Ding, D.X. and Yip, N. (2013), "Outcome-based contracts as new business model: the role of partnership and value-driven relational assets”, Industrial Marketing Management, Vol. 42 No. 5, pp. 730-743.

Oliva, R. and Kallenberg, R. (2003), "Managing the transition from products to services", International Journal of Service Industry Management, Vol. 14 No. 2, pp. 160-172.

Ozment, J. and Morash, E.A. (1994), "The augmented service offering for perceived and actual service quality", Journal of the Academy of Marketing Science, Vol. 22 No. 4, pp. 352-363.

Pemer, F., Sieweke, J., Werr, A., Birkner, S. and Mohe, M. (2014), "The cultural embeddedness of professional service purchasing - a comparative study of German and Swedish companies", Journal of Purchasing and Supply Management, Vol. 20 No. 4, pp. 273-285.

Ponsignon, F., Smart, P.A. and Maull, R.S. (2011), "Service delivery system design: characteristics and contingencies", International Journal of Operations \& Production Management, Vol. 31 No. 3, pp. 324-349.

Poppo, L. and Zenger, T. (2002), "Do formal contracts and relational governance function as substitutes or complements?”, Strategic Management Journal, Vol. 23 No. 8, pp. 707-725.

Powers, T.L., Sheng, S. and Li, J.J. (2016), "Provider and relational determinants of customer solution performance", Industrial Marketing Management, Vol. 56, pp. 14-23.

Ramsay, J., Wagner, B. and Kelly, S. (2013), "Purchase offering quality: the effects of buyer behaviour on organizational supplying behaviour", International Journal of Operations \& Production Management, Vol. 33 No. 10, pp. 1260-1282.

Reim, W., Parida, V. and Örtqvist, D. (2015), "Product-service systems (PSS) business models and tactics - a systematic literature review", Journal of Cleaner Production, Vol. 97, pp. 61-75.

Roberts, K., Varki, S. and Brodie, R. (2003), "Measuring the quality of relationships in consumer services: an empirical study", European Journal of Marketing, Vol. 37 Nos 1/2, pp. 169-196. 
IJOPM

39,4

Robinson, H.S. and Scott, J. (2009), "Service delivery and performance monitoring in PFI/PPP projects", Construction Management and Economics, Vol. 27 No. 2, pp. 181-197.

Roehrich, J. and Lewis, M. (2014), "Procuring complex performance: implications for exchange governance complexity”, International Journal of Operations \& Production Management, Vol. 34 No. 2, pp. 221-241.

Roehrich, J.K. and Lewis, M.A. (2010), "Towards a model of governance in complex (product-service) inter-organizational systems", Construction Management and Economics, Vol. 28 No. 11, pp. 1155-1164.

Schmoltzi, C. and Wallenburg, C.M. (2012), "Operational governance in horizontal cooperations of logistics service providers: performance effects and the moderating role of cooperation complexity", Journal of Supply Chain Management, Vol. 48 No. 2, pp. 53-74.

Selviaridis, K. and Spring, M. (2010), "The dynamics of business service exchanges: insights from logistics outsourcing", Journal of Purchasing and Supply Management, Vol. 16 No. 3, pp. 171-184.

Selviaridis, K. and Spring, M. (2018), "Supply chain alignment as process: contracting, learning and pay-for-performance", International Journal of Operations \& Production Management, Vol. 38 No. 3, pp. $732-755$.

Silvestro, R. (1999), "Positioning services along the volume-variety diagonal: the contingencies of service design, control and improvement", International Journal of Operations \& Production Management, Vol. 19 No. 4, pp. 399-421.

Silvestro, R., Fitzgerald, L., Johnston, R. and Voss, C. (1992), "Towards a classification of service processes", International Journal of Service Industry Management, Vol. 3 No. 3, pp. 62-75.

Singleton, R.A. and Straits, B.C. (2009), Approaches to Social Research, Oxford University Press, New York, NY.

Skeels, M.M. and Grudin, J. (2009), "When social networks cross boundaries: a case study of workplace use of Facebook and LinkedIn", Proceedings of the ACM 2009 International Conference on Supporting Group Work, ACM, pp. 95-104.

Smeltzer, L.R. and Ogden, J.A. (2002), "Purchasing professionals' perceived differences between purchasing materials and purchasing services", Journal of Supply Chain Management, Vol. 38 No. 4, pp. 54-70.

Smith, B. (1998), "Buyer-seller relationships: bonds, relationship management, and sex-type", Canadian Journal of Administrative Sciences/Revue Canadienne des Sciences de l'Administration, Vol. 15 No. 1, pp. 76-92.

Stauss, B., Nordin, F. and Kowalkowski, C. (2010), "Solutions offerings: a critical review and reconceptualisation”, Journal of Service Management, Vol. 21 No. 4, pp. 441-459.

Stouthuysen, K., Slabbinck, H. and Roodhooft, F. (2012), “Controls, service type and perceived supplier performance in interfirm service exchanges", Journal of Operations Management, Vol. 30 No. 5, pp. 423-435.

Susarla, A., Barua, A. and Whinston, A.B. (2009), "A transaction cost perspective of the 'software as a service' business model”, Journal of Management Information Systems, Vol. 26 No. 2, pp. 205-240.

Tukker, A. (2004), "Eight types of product-service system: eight ways to sustainability? Experiences from SusProNet", Business Strategy and the Environment, Vol. 13 No. 4, pp. 246-260.

United States Census Bureau (2014), "North American industry classification system", available at: www.census.gov/eos/www/naics/ (accessed May 28, 2015).

Van Der Valk, W. and Rozemeijer, F. (2009), "Buying business services: towards a structured service purchasing process", Journal of Services Marketing, Vol. 23 No. 1, pp. 3-10.

Van Der Valk, W. and Van Iwaarden, J. (2011), "Monitoring in service triads consisting of buyers, subcontractors and end customers", Journal of Purchasing and Supply Management, Vol. 17 No. 3, pp. 198-206. 
Van Der Valk, W. and Wynstra, F. (2012), "Buyer-supplier interaction in business-to-business services: a typology test using case research", Journal of Purchasing and Supply Management, Vol. 18 No. 3, pp. 137-147.

Van Der Valk, W. and Wynstra, F. (2014), "Variety in business-to-business services and buyer-supplier interaction: the case of cleaning services", International Journal of Operations \& Production Management, Vol. 34 No. 2, pp. 195-220.

Van Der Valk, W., Sumo, R., Dul, J. and Schroeder, R.G. (2016), "When are contracts and trust necessary for innovation in buyer-supplier relationships? A necessary condition analysis", Journal of Purchasing and Supply Management, Vol. 22 No. 4, pp. 266-277.

Wacker, J.G., Yang, C. and Sheu, C. (2016), "A transaction cost economics model for estimating performance effectiveness of relational and contractual governance: theory and statistical results", International Journal of Operations \& Production Management, Vol. 36 No. 11, pp. 1551-1575.

Wathne, K.H. and Heide, J.B. (2000), "Opportunism in interfirm relationships: forms, outcomes, and solutions", Journal of Marketing, Vol. 64 No. 4, pp. 36-51.

Whang, S. (1992), "Contracting for software development", Management Science, Vol. 38 No. 3, pp. 307-324.

Williamson, O.E. (1985), The Economic Institutions of Capitalism, Simon and Schuster, New York, NY.

Williamson, O.E. (1991), "Comparative economic organization: the analysis of discrete structural alternatives", Administrative Science Quarterly, Vol. 36 No. 2, pp. 269-296.

Wynstra, F., Rooks, G. and Snijders, C. (2018), "How is service procurement different from goods procurement? Exploring ex ante costs and ex post problems in IT procurement", Journal of Purchasing and Supply Management, Vol. 24 No. 2, pp. 83-94.

Zheng, J., Roehrich, J.K. and Lewis, M.A. (2008), "The dynamics of contractual and relational governance: evidence from long-term public-private procurement arrangements", Journal of Purchasing and Supply Management, Vol. 14 No. 1, pp. 43-54.

$\mathrm{Zu}, \mathrm{X}$. and Kaynak, H. (2012), "An agency theory perspective on supply chain quality management", International Journal of Operations \& Production Management, Vol. 32 No. 4, pp. 423-446.

\section{Corresponding author}

Wenting Zou can be contacted at: wenting.zou@aalto.fi

For instructions on how to order reprints of this article, please visit our website: 